\title{
Hydrogen Permeation Behavior of Scratch on Zn Coated Steel during 1000 Hours Wet and Dry Corrosion Test
}

\author{
Kei SAKATA, ${ }^{1{ }^{*}}$ Masatoshi SAKAIRII) and Junichiro KINUGASA ${ }^{3)}$ \\ 1) Graduate School of Engineering, Hokkaido University, Kita-13, Nishi-8, Kita-ku, Sapporo, Hokkaido, Japan. \\ 2) Faculty of Engineering, Hokkaido University, Kita-13, Nishi-8, Kita-ku, Sapporo, Hokkaido, Japan. \\ 3) Materials Research Laboratory, Kobe Steel Ltd., 1-5-5 Takatsukadai, Nishi-ku, Kobe, Hyogo, 651-2271 Japan.
}

(Received on May 29, 2020; accepted on August 3, 2020)

\begin{abstract}
In this study, hydrogen permeation current from scratch formed on Zn coated steel during $1000 \mathrm{~h}$ wet and dry cyclic corrosion test was investigated. The scratch was fabricated by focused pulsed Nd: YAG laser irradiation. The obtained hydrogen permeation current has peaks during wetting, and the peak currents decrease with time. Formation of $\mathrm{Zn}$ corrosion products prevent hydrogen entry. After the test, there are $\mathrm{Zn}$ oxide $(\mathrm{ZnO})$ on the substrate steel, hydrozincite $\left(\mathrm{Zn}_{5}(\mathrm{OH})_{6}\left(\mathrm{CO}_{3}\right)_{2}\right)$ around the scratch boundary and simonkolleite $\left(\mathrm{Zn}_{5}(\mathrm{OH})_{8} \mathrm{Cl}_{2}\right)$ on $\mathrm{Zn}$ coated region. It is suggested that $\mathrm{pH}$ change with distance from the formed scratch is the reason for the composition of $\mathrm{Zn}$ corrosion products change with location.
\end{abstract}

KEY WORDS: electrochemical permeated hydrogen detection; Zn coated steel; scratch; laser fabrication; simulated atmospheric corrosion environment.

\section{Introduction}

Strength of steels has been increasing and using high strength steels enable us to reduce thickness. However, it is important issue that increasing strength of steels usually leads to high susceptibility of hydrogen embrittlement. ${ }^{1-5)}$ Hydrogen embrittlement is a phenomenon in which the ductility of steel decreases due to hydrogen absorbed in steel. In order to use high-strength steels safely, hydrogen embrittlement has been widely studied. Hydrogen entry occurs during welding, pickling, electroplating and corroding. Corrosion in atmospheric environments plays an important role in hydrogen embrittlement in actual environments.

In order to prevent corrosion, $\mathrm{Zn}$ coated steels are widely used. Shinohara reported that the average corrosion rate of $\mathrm{Zn}$ was about $1 / 26$ that of Fe. ${ }^{6}$ ) $\mathrm{Zn}$ coated steels are inexpensive and have excellent protective film function and sacrificial protection properties, therefore, it is widely used in automotive and building materials.

The protective film function of $\mathrm{Zn}$ coating is achieved by formation of stable $\mathrm{Zn}$ oxide films formed on the materials. $\mathrm{Zn}$ dissolved zinc ions $\left(\mathrm{Zn} \rightarrow \mathrm{Zn}^{2+}+2 \mathrm{e}^{-}\right)$, which cause a hydrolysis reaction to form zinc hydroxide $\left(\mathrm{Zn}^{2+}+\mathrm{H}_{2} \mathrm{O} \rightarrow\right.$ $\left.\mathrm{Zn}(\mathrm{OH})_{2}+2 \mathrm{H}^{+}\right)$. Zinc hydroxide $\left(\mathrm{Zn}(\mathrm{OH})_{2}\right)$ dehydrates to $\mathrm{Zinc}$ oxide $(\mathrm{ZnO})$ when humidity is low. These oxides form the protective layers. The protective layers are dense and have good adhesiveness and high corrosion resistance.

\footnotetext{
* Corresponding author: E-mail: k.sakata@frontier.hokudai.ac.jp
}

It is known that $\mathrm{Zn}$ compounds containing environmental anions such as $\mathrm{SO}_{4}{ }^{2-}$ and $\mathrm{Cl}^{-}$are formed by long-term exposure in an atmospheric corrosive environment. ${ }^{7-10}$ ) Figure 1 is a schematic diagram showing the change of the corrosion products with time during exposing to the atmosphere. Under atmospheric conditions, hydrozincite $\left(\mathrm{Zn}_{5}\left(\mathrm{CO}_{3}\right)_{2}(\mathrm{OH})_{6}\right)$ is formed. Simonkolleite $\left(\mathrm{Zn}_{5}(\mathrm{OH})_{8} \mathrm{Cl}_{2}\right)$ is formed in the marine atmosphere and $\mathrm{Zn}_{4} \mathrm{SO}_{4}(\mathrm{OH})_{6} \cdot \mathrm{nH}_{2} \mathrm{O}$ is formed in the rural atmosphere after long exposure periods. It is known that $\mathrm{Zn}$ corrosion products in atmospheric corrosion consist of Zinc hydroxide, Zinc oxide, hydrozinc-

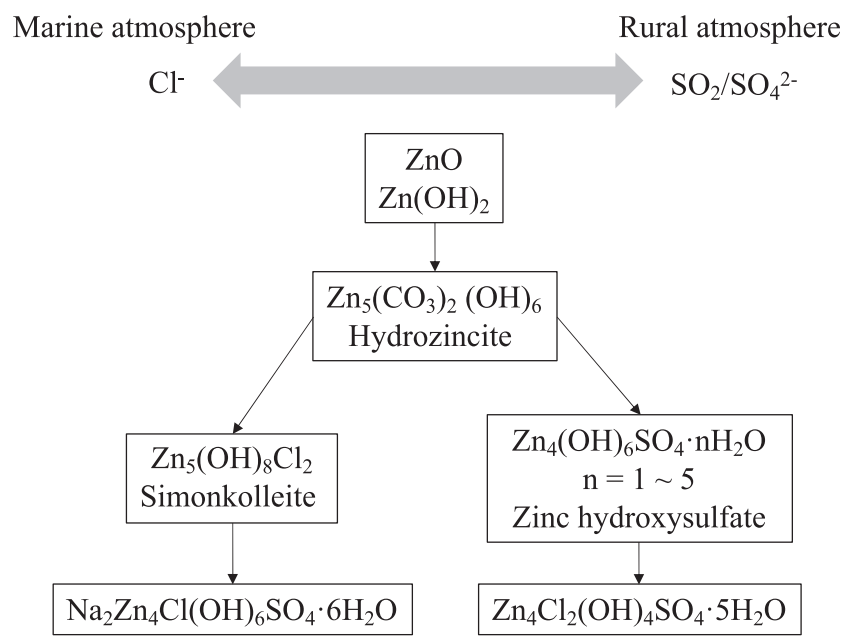

Fig. 1. Changes of $\mathrm{Zn}$ corrosion product with time. ${ }^{7-10)}$ 
ite, Simonkolleite and so on.

The sacrificial protection properties is an action in which $\mathrm{Zn}$ dissolves preferentially over steel. When a scratch forms on $\mathrm{Zn}$ coated steel, the sacrificial protection reaction occur. $\mathrm{Zn}$ around the scratch is dissolved preferentially over the substrate steel (anodic reaction: $\mathrm{Zn} \rightarrow \mathrm{Zn}^{2+}+2 \mathrm{e}^{-}$). Hydrogen generation reaction (cathodic reaction: $2 \mathrm{H}^{+}+$ $2 \mathrm{e}^{-} \rightarrow \mathrm{H}_{2}$ ) increases at exposed substrate steel surface due to the cathodic polarization. Therefore, hydrogen entry also increases, which also increases the risk of hydrogen embrittlement. Tada et al. reported hydrogen permeation current during $150 \mathrm{~h}$ wet and dry cycle test. ${ }^{11)}$ Hydrogen permeation behavior of $\mathrm{Zn}$ coated steel during long term wet and dry corrosion test is still not fully elucidated. In this paper, the micro-electrochemical hydrogen detection cell was introduced to investigate hydrogen permeation behavior of scratch formed on $\mathrm{Zn}$ coated steel during $1000 \mathrm{~h}$ wet and dry cycle corrosion.

\section{Experimental}

\subsection{Specimen}

$\mathrm{Zn}$ coated steel sheet $(15 \times 30 \times 0.5 \mathrm{~mm})$ was used as specimen. One side of the specimen (hydrogen detection side) was ground with $\mathrm{SiC}$ abrasive paper up to \#1500 grit size in order to remove precoated $\mathrm{Zn}$ layer, and the surface was plated electrochemically with $\mathrm{Ni}$ in $0.312 \mathrm{kmol} \mathrm{m}^{-3}$ $\mathrm{NiSO}_{4} / 0.781 \mathrm{kmol} \mathrm{m}^{-3} \mathrm{H}_{3} \mathrm{BO}_{3}$ solution at $4 \mathrm{~mA} \mathrm{~cm}{ }^{-2}$ for 720 s. The thickness of Ni plated layer was $1 \mu \mathrm{m}$. The other side of the specimen (the hydrogen entry side of the specimen) was irradiated by pulsed Nd: YAG laser (wavelength 532 $\mathrm{nm}$, pulse duration $8 \mathrm{~ns}$, pulse frequency $10 \mathrm{~s}^{-1}$, and power $20 \mathrm{~mW}$ at the front of the lens) in the highly purified water to form the scratches. The shape of scratch was $1440 \times 1440$ $\mu \mathrm{m}^{2}$. Finally, the specimen were cleaned, in highly purified water and ethanol using ultrasonic baths for $300 \mathrm{~s}$.

\subsection{Wet and Dry Corrosion Test}

The schematic representations of (a) top view and (b) cross-section of micro-electrochemical hydrogen detection cell were shown in Fig. 2. Pt wires were used as the counter electrode (C.E.) and the reference electrode (R.E.) in the hydrogen detection cell (bottom in Fig. 2 (b)).

Solution of $1 \mathrm{kmol} \mathrm{m}^{-3} \mathrm{NaOH}$ was filled in the hydrogen detection cell and the specimen of the hydrogen detection (the nickel plated) side was placed on the cell. It was ensured that there were no bubbles in the cell. After the specimen was set the cell, the cell was placed in humidity and temperature control chamber. To measure the hydrogen which was generated by the corrosion and permeating through the specimen, hydrogen detection side of the specimen was polarized at $-30 \mathrm{mV}$ vs. Pt during the wet and dry corrosion tests. This applied anodic potential was sufficient to ionize any hydrogen reaching at the surface after permeating through the specimen. After the current of the hydrogen detection cell reached a sufficiently low and steady value under $10 \mathrm{nA}$ (about $86.4 \mathrm{ks}$ after the potential was applied), $10 \mu \mathrm{L}$ of 0.1 $\mathrm{kmol} \mathrm{m}{ }^{-3} \mathrm{NaCl}$ solution was dropped on the center of the scratch. After dropping, wet and dry cyclic corrosion test and the measurement of hydrogen permeation current was started. In wet and dry cyclic corrosion test, one cycle was divided into four processes, $1 \mathrm{~h}$ wetting process (maintained at $90 \% \mathrm{RH}), 1 \mathrm{~h}$ transition process, $3 \mathrm{~h}$ drying process $(33 \% \mathrm{RH})$ and $1 \mathrm{~h}$ transition process. The temperature was controlled at $298 \mathrm{~K}$. The total wet and dry corrosion period was $1000 \mathrm{~h}$.

\subsection{Surface Observation and Analysis}

The surface of the specimen after the test was observed with an optical microscope and a scanning electron microscope (SEM). An energy dispersive X-ray spectroscope (EDS), a Raman spectroscope, a X-ray photoelectron spectroscope (XPS) and an Auger electron spectroscope (AES) were used to analyze the surface of specimen.

\section{Results and Discussion}

\subsection{Hydrogen Permeation Current during $1000 \mathrm{~h}$ Wet and Dry Corrosion Test}

Figure 3 shows the hydrogen permeation current during $1000 \mathrm{~h}$ wet and dry corrosion test. The largest peak value of $55 \mathrm{nA}$ is observed at first cycle. The peak currents decrease with time. From Fig. 4, current peaks are observed at wetting period. The peak during (c) $282-354 \mathrm{~h}$ is $10-20 \mathrm{nA}$, which are less than half of the initial peak at the first cycle in (b). Almost no peaks are observed during (d) 924-996 h. Igarash et al. reported that during about $60 \mathrm{~h}$ wet and dry cycle, hydrogen permeation current of $\mathrm{Zn}$ and $\mathrm{Zn}-\mathrm{Al}$ coated steels were decrease with cycle number. They proposed that corrosion products inhibited hydrogen entry. ${ }^{12)}$ (a)

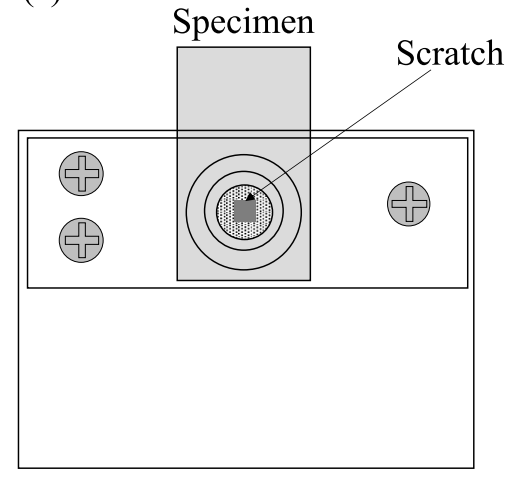

(b)

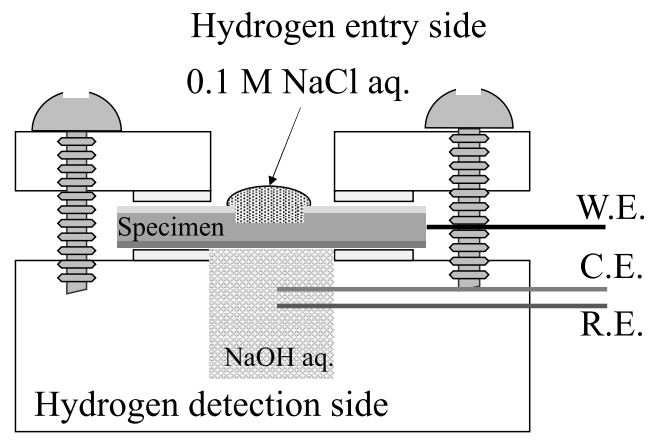

Fig. 2. Schematic representation of the electrochemical cell and specimen for hydrogen permeation test. (a) top view and (b) cross section. 


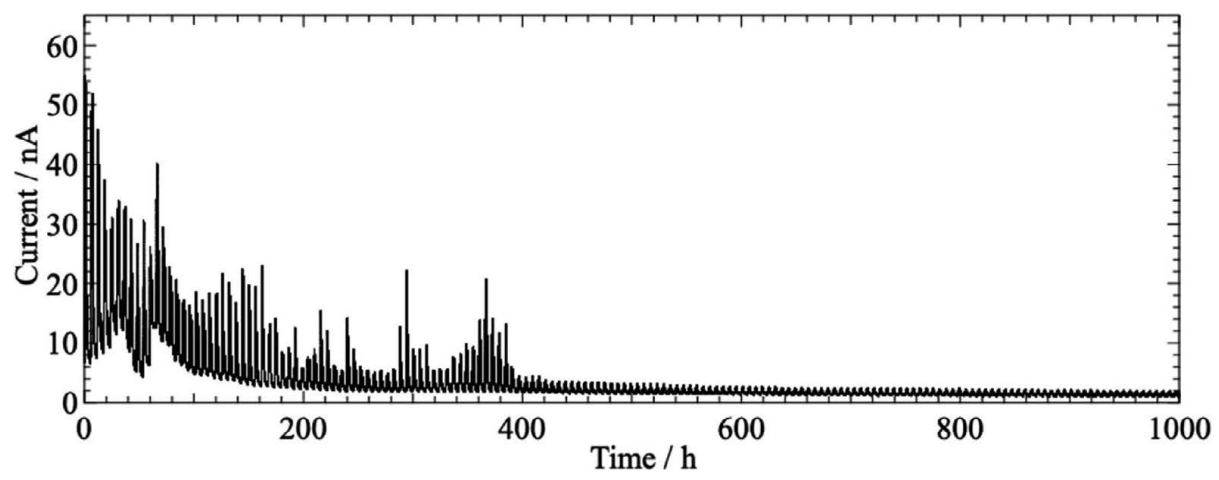

Fig. 3. Changes in hydrogen permeation current during $1000 \mathrm{~h}$ wet and dry corrosion test.
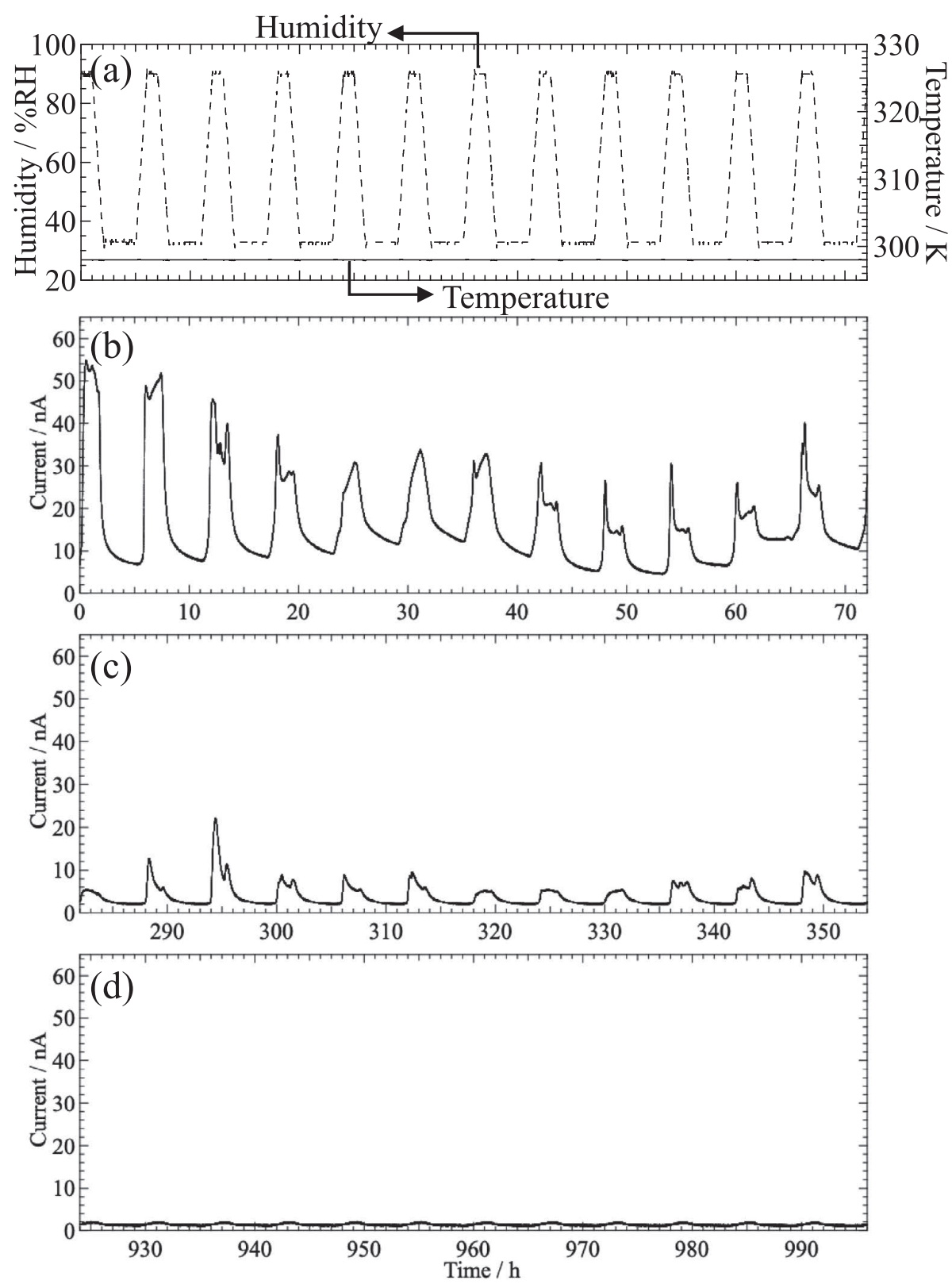

Fig. 4. Changes in (a) humidity and temperature and changes in hydrogen permeation current during $1000 \mathrm{~h}$ during (b) 0-72 h, (c) 282-354 h and (d) 924-996 h.

\subsection{Surface Observation and Analysis after Wet and Dry Corrosion Test}

In order to clarify effect of corrosion products, surface observation and analysis were carried out. Figure 5 shows optical microscope images of the specimen surface (a) before wet and dry corrosion test and (b) after the test, and (c) the tested specimen after ultrasonic cleaning. The dark square in the center (Fig. 5(a)) is the formed scratch. After the wet and dry corrosion test (Fig. 5(b)), there are white corrosion products around the scratch. After ultrasonic 
cleaning of the specimen (Fig. 5(c)), some of the corrosion products still remain on the scratch. From this result, formed corrosion products have good adhesiveness to the substrate.

Figure 6 shows (a) SEM image and (b)-(f) elemental mapping at the scratch after ultrasonic cleaning of the specimen. From Fig. 6(b), Fe which is considered to be substrate steel is detected. From Figs. 6(c), 6(d) and 6(e), Zn, Cl and $\mathrm{O}$ are detected around the scratch. It is suggested that the
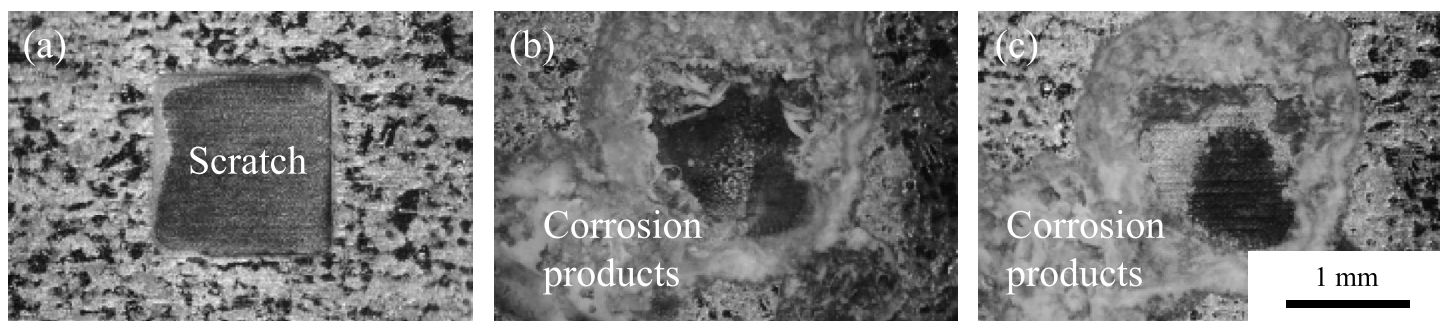

Fig. 5. Optical microscope images of the specimen surface (a) before and (b) after the wet and dry corrosion test, and (c) the tested specimen after ultrasonic cleaning.
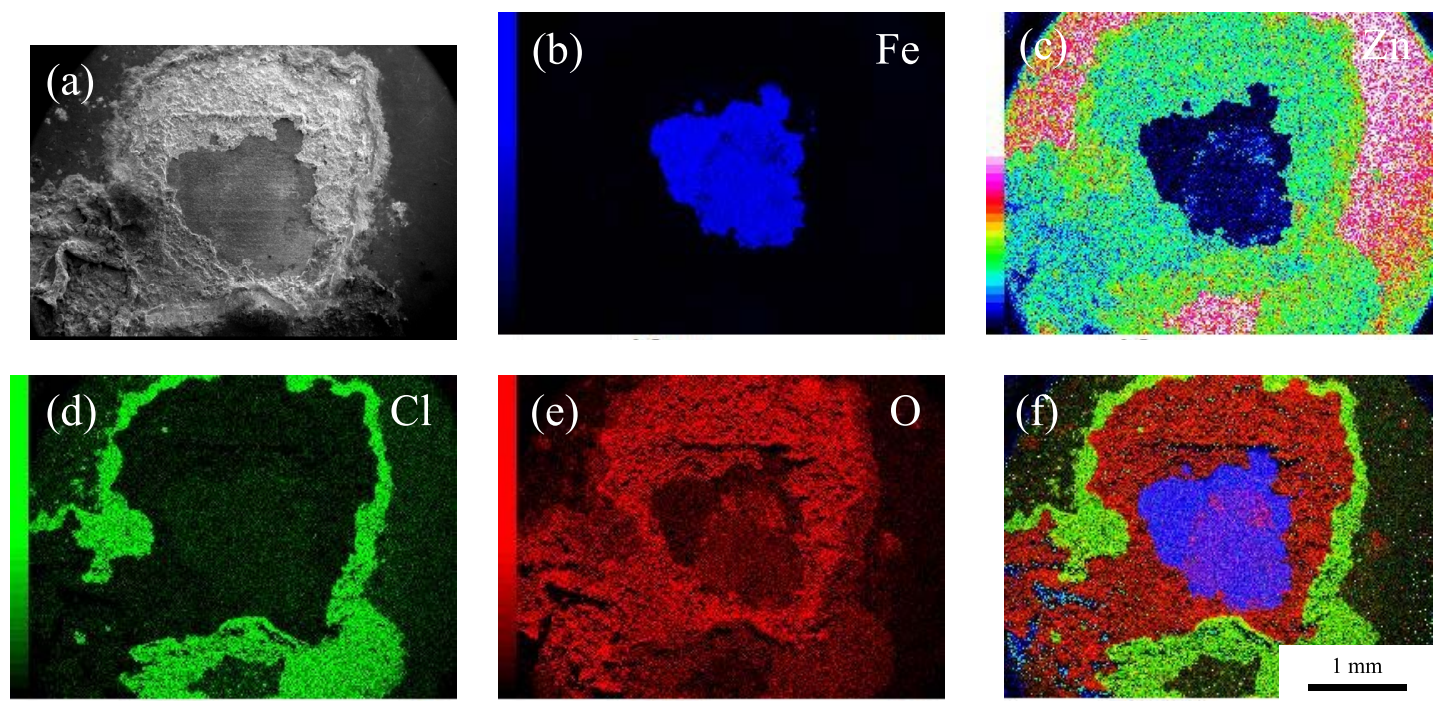

Fig. 6. (a) SEM image at scratch on specimen after wet and dry corrosion test. Elemental mapping by EDS, (b) Fe, (c) $\mathrm{Zn}$, (d) $\mathrm{Cl}$ and (e) O. (f) Superposition of four elemental mappings. (Online version in color.)
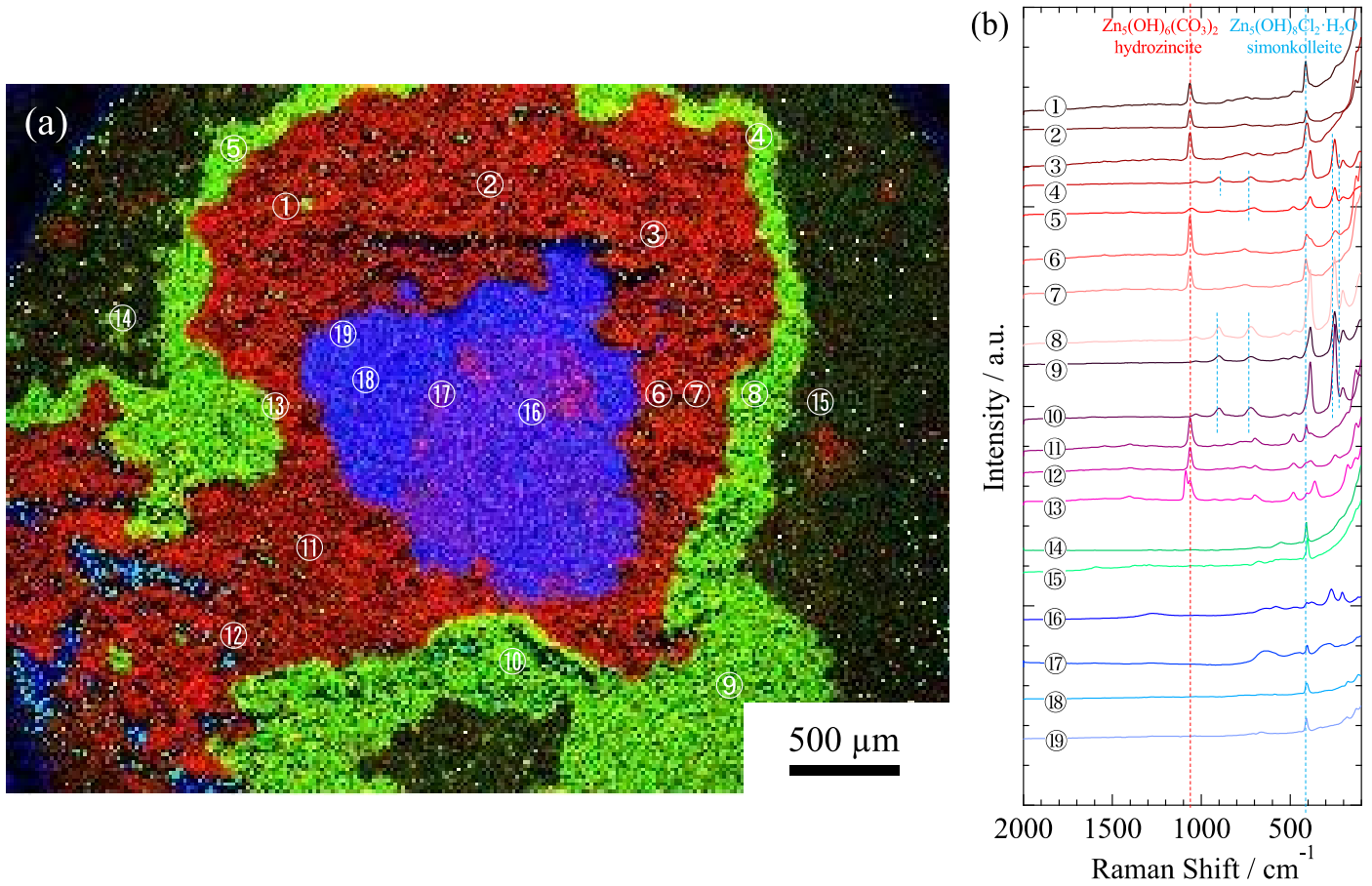

Fig. 7. (a) Superposition of elemental mapping same as Fig. 6(f) and (b) Raman spectra of the specimen surface. (Online version in color.) 
corrosion products are made of $\mathrm{Zn}, \mathrm{Cl}$ and $\mathrm{O}$. Figure 6(f) is the superposition of these four elemental mappings. From Fig. 6(f), there are high Fe intensity regions (blue) in the center at scratch, and there are high $\mathrm{O}$ intensity regions (red) around it. High $\mathrm{Cl}$ intensity regions (green) are observed around the high $\mathrm{O}$ intensity regions (red). From EDS analysis, $\mathrm{Zn}$ corrosion products may change with distance from the formed scratch.

To investigate the difference of $\mathrm{Zn}$ corrosion products at high $\mathrm{O}$ and $\mathrm{Cl}$ intensity region, Raman spectroscopy was carried out. Figure 7 shows (a) the superposition of elemental mapping shown in Fig. 6(f), and (b) Raman spectra of the specimen surface. In Fig. 7(b), there are peaks at $1060 \mathrm{~cm}^{-1}$ and $390 \mathrm{~cm}^{-1}$. The peak of $1060 \mathrm{~cm}^{-1}$ is corresponding to hydrozincite $\left(\mathrm{Zn}_{5}(\mathrm{OH})_{6}\left(\mathrm{CO}_{3}\right)_{2}\right)$ and the peak at $390 \mathrm{~cm}^{-1}$ is corresponding to simonkolleite $\left(\mathrm{Zn}_{5}(\mathrm{OH})_{8} \mathrm{Cl}_{2} \cdot \mathrm{H}_{2} \mathrm{O}\right){ }^{7-9,13)}$ In the high $\mathrm{O}$ intensity regions (red) (1), (2), (3), (6), (7), (11), (12) and (13) in Fig. 7(a), the hydrozincite peak at $1060 \mathrm{~cm}^{-1}$ is observed. In the high $\mathrm{Cl}$ intensity regions (green) (4), (5), (8), (9) and (10) in Fig. 7(a), there is the simonkolleite peak at 390 $\mathrm{cm}^{-1}$. In addition, the hydrozincite peak at $1060 \mathrm{~cm}^{-1}$ is hardly observed. These results indicate that hydrozincite and simonkolleite exist in the high $\mathrm{O}$ intensity regions, while only simonkolleite exists in the high $\mathrm{Cl}$ intensity regions.

For better understanding chemical composition of these $\mathrm{Zn}$ corrosion products, the specimen after the wet and dry corrosion test was investigated by XPS. Figure 8 shows the XPS wide spectrum of the specimen after the test. The peaks are assigned to $\mathrm{Zn}, \mathrm{O}, \mathrm{Fe}, \mathrm{C}$ and $\mathrm{Cl}{ }^{14)}$ These elements may are derived from the $\mathrm{Zn}$ corrosion products, substrate steel or contaminated carbon. Figure 9 shows the XPS narrow spectra of (a) O 1s, (b) Zn 2p $3 / 2$ and (c) C 1s at the scratch center and $\mathrm{Zn}$ coating region. In Figs. 9(a) and 9(b), the obtained spectra may be simonkolleite or hydrozincite. ${ }^{15)} \mathrm{C}$ 1s (Fig. 9(c)) spectra has two peaks; one is carbonates $\left(\mathrm{CO}_{3}\right)$ and the other is contamination carbon $(\mathrm{C}-\mathrm{C}) .{ }^{15)}$ From $\mathrm{C} 1 \mathrm{~s}$ spectra, existence of hydorzincite in the corrosion products is confirmed.

Islam et al. reported that $\mathrm{Zn}^{2+}$ in the solution easily forms thin $\mathrm{Zn}$ protective layer on the steel surface after immersion test. ${ }^{16,17)}$ It is seemed that a thin $\mathrm{Zn}$ protective layer existed on the scratch. AES surface analysis which can measure the thin surface layer was carried out. Figure 10 shows (a) SEM image and (b) AES spectra. The peaks are assigned to $\mathrm{O}(503 \mathrm{eV}), \mathrm{Fe}(599,652,704 \mathrm{eV})$ and $\mathrm{Zn}(990 \mathrm{eV}) .{ }^{18)}$ The $\mathrm{O}$ and $\mathrm{Zn}$ peaks are observed at each position. The Fe peaks are only observed at (4), the scratch center. The $\mathrm{Zn}$ peak at (4) is analyzed in detail. Figure 11 shows the standard spectra of (a) $\mathrm{ZnO}$ and (b) Zn. Figure 11(c) shows the obtained spectrum with the convolution of the $\mathrm{ZnO}$ and $\mathrm{Zn}$ standard spectrum by least-squares method and the residual spectrum. The $\mathrm{ZnO}$ and $\mathrm{Zn}$ standard spectrum are magnified using magnification percentage in Table 1. Tsutsumi et al. reported that since the Auger transition involves outer shell electrons, the shape of the Auger peak reflects the chemical state of the specimen. ${ }^{19-22)}$ It is possible to analyze and quantify the chemical state by comparing the obtained spectrum with the standard spectrum. The calculated existence ratio

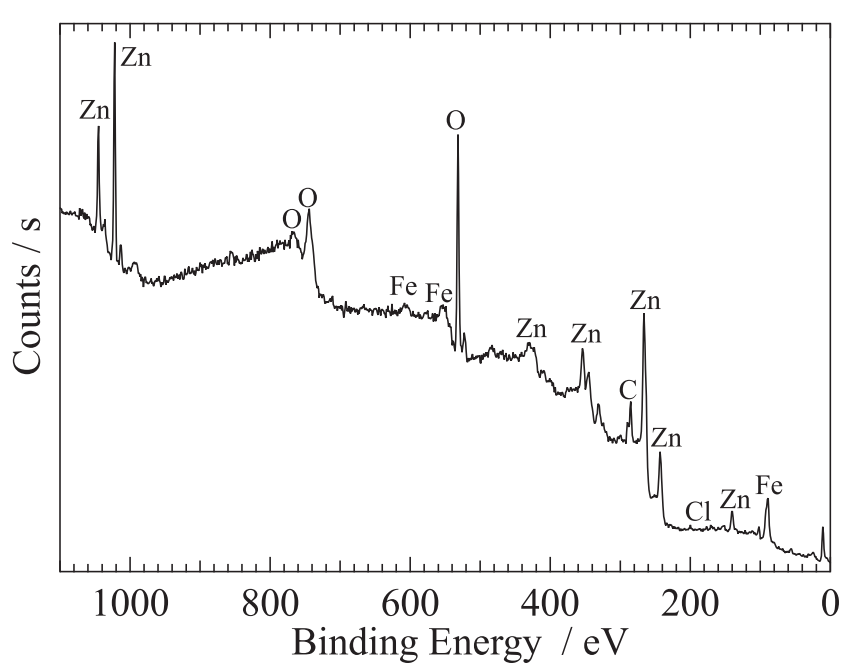

Fig. 8. XPS wide spectrum at scratch center of the specimen after wet and dry corrosion test.

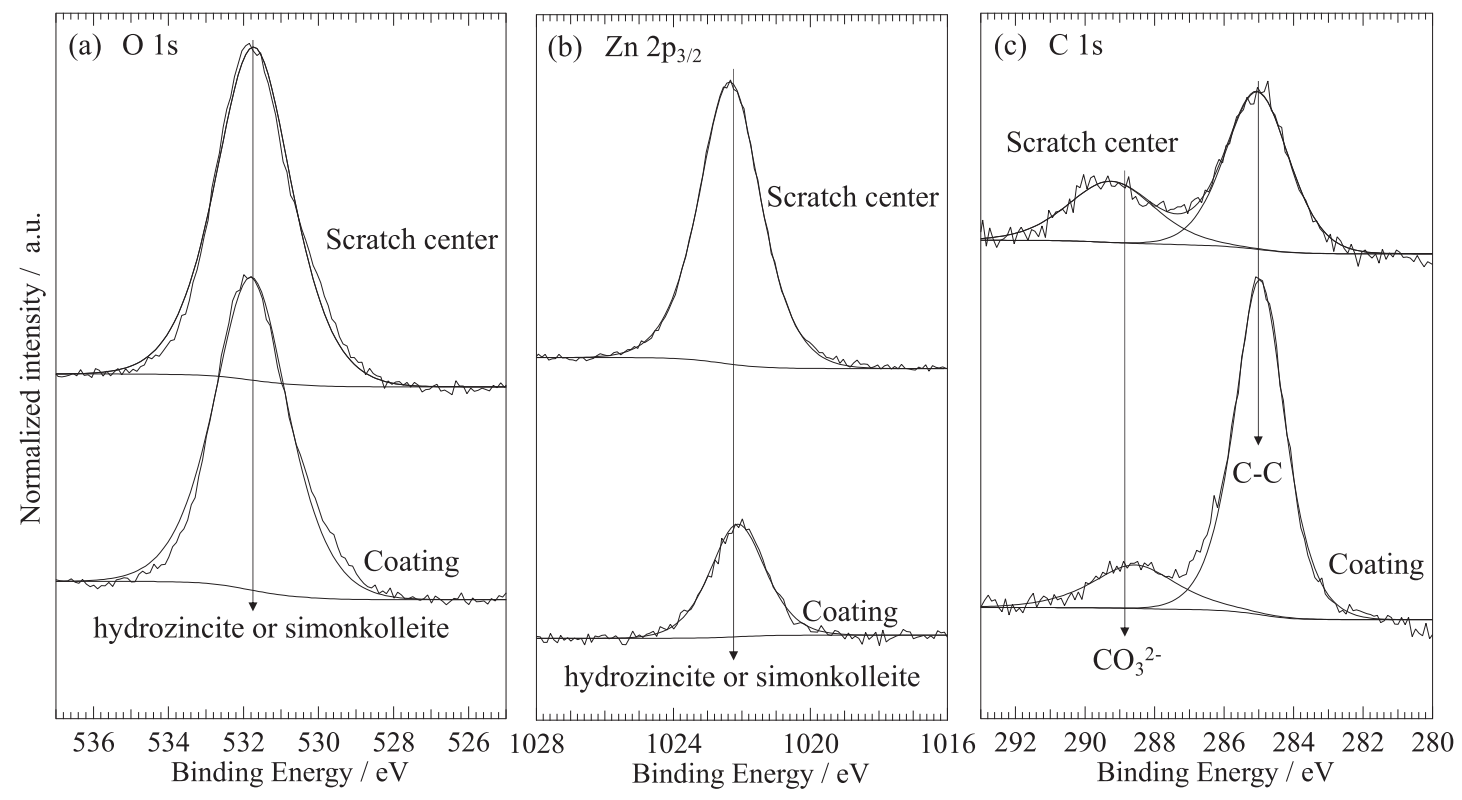

Fig. 9. XPS narrow spectra of (a) $\mathrm{O} 1 \mathrm{~s}$, (b) $\mathrm{Zn} 2 \mathrm{p}_{3 / 2}$, (c) $\mathrm{C}$ 1s at scratch center and $\mathrm{Zn}$ coating region. 

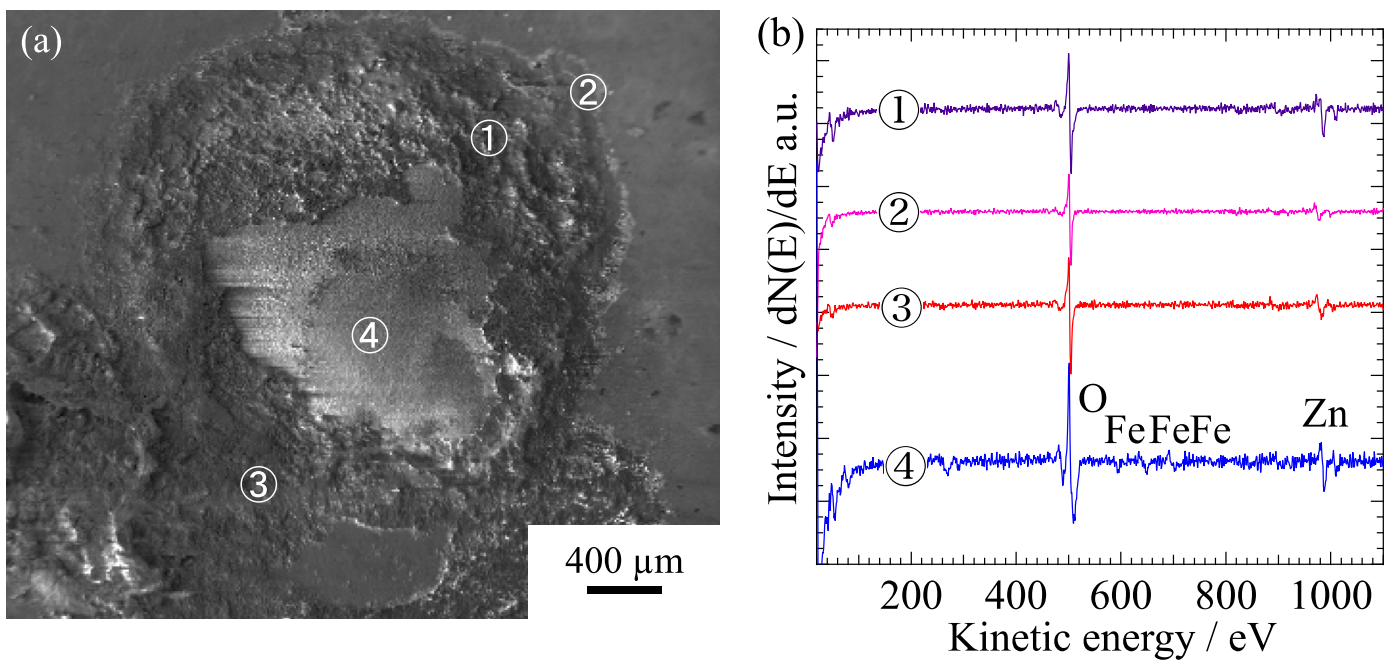

Fig. 10. (a) SEM image with analysis points and (b) AES spectra of the specimen surface. (Online version in color.)

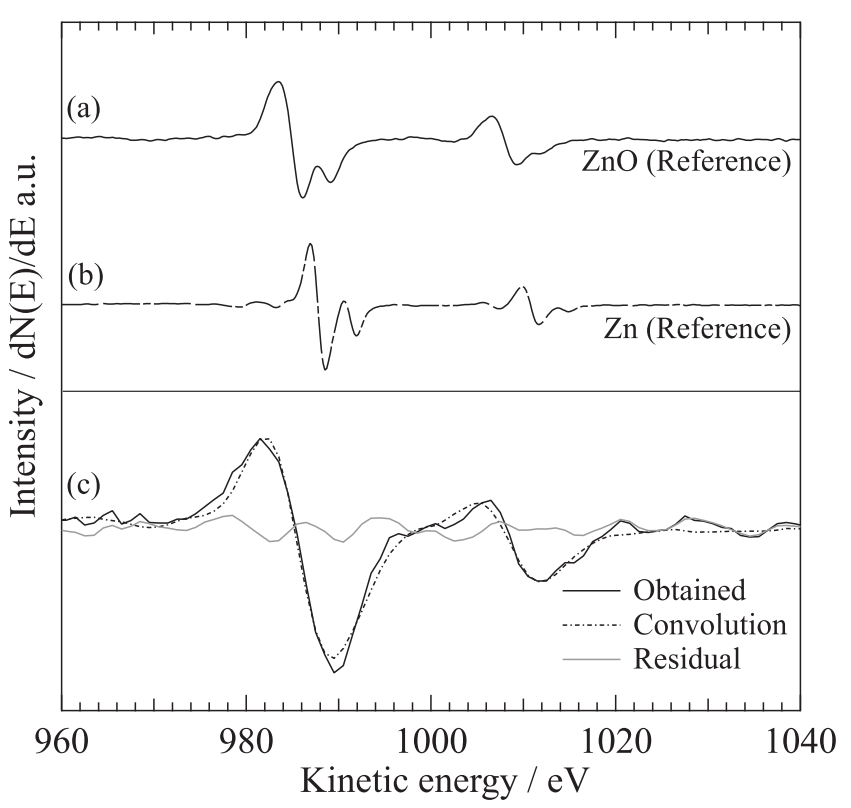

Fig. 11. AES spectra of $\mathrm{Zn}$ from 960 to $1040 \mathrm{eV}$. The standard spectra of reference materials, (a) $\mathrm{ZnO}$ and (b) $\mathrm{Zn}$. (c) Obtained spectrum with (d) Convolution curve and Residual curve.

from the magnification is $98.6 \%$ for $\mathrm{ZnO}$ and $1.4 \%$ for $\mathrm{Zn}$. This result suggests that $\mathrm{ZnO}$ existing on the steel substrate inhibits hydrogen entry.

\subsection{Changes in Zn Corrosion Products with Deposition Position}

From surface analysis results, $\mathrm{Zn}$ corrosion products change with distance from the formed scratch. Manhabosco et al. reported the difference of $\mathrm{Zn}$ corrosion products deposited on low-angle cross section of $\mathrm{Zn}$ coated steel. ${ }^{23}$ ) Hydrozincite are deposited on the coating/steel interface and simonkolleite are deposited on the outer $\mathrm{Zn}$ coating region. Okada et al. reported $\mathrm{pH}$ change with $\mathrm{Fe} / \mathrm{Zn}$ interface by numerical analysis. ${ }^{24)}$ In this section, the condition for forming simonkolleite and hydrozincite with $\mathrm{pH}$ are calculated.

In the beginning, $\mathrm{CO}_{2}$ dissolves in water and dissociate. At $298 \mathrm{~K}$, the equilibrium constant is ${ }^{25)}$

Table 1. Magnification factor of standard materials spectra and existence ratio of $\mathrm{Zn}$ and $\mathrm{Zn}^{2+}$.

\begin{tabular}{ccc}
\hline Material & Magnification & Existence ratio \\
\hline $\mathrm{Zn}$ & 0.002 & $1.4 \%(\mathrm{Zn})$ \\
$\mathrm{ZnO}$ & 0.284 & $98.6 \%\left(\mathrm{Zn}^{2+}\right)$ \\
\hline
\end{tabular}

$$
\begin{gathered}
\mathrm{CO}_{2}(\mathrm{~g})+\mathrm{H}_{2} \mathrm{O}(\mathrm{l}) \rightleftharpoons \mathrm{H}_{2} \mathrm{CO}_{3} \text { (aq.) } \\
K_{1}=\frac{\left[\mathrm{H}_{2} \mathrm{CO}_{3}\right]}{P_{c o_{2}}}=3.39 \times 10^{-2} \\
\log K_{1}=-1.47 \\
\mathrm{H}_{2} \mathrm{CO}_{3} \rightleftharpoons \mathrm{HCO}_{3}^{-}+\mathrm{H}^{+} \\
K_{2}=\frac{\left[\mathrm{HCO}_{3}^{-}\right]\left[\mathrm{H}^{+}\right]}{\left[\mathrm{H}_{2} \mathrm{CO}_{3}\right]}=4.45 \times 10^{-7}
\end{gathered}
$$

$\log K_{2}=-6.35$

$$
\begin{aligned}
\mathrm{HCO}_{3}{ }^{-} & \rightleftharpoons \mathrm{CO}_{3}{ }^{2-}+\mathrm{H}^{+} \\
K_{3} & =\frac{\left[\mathrm{CO}_{3}{ }^{-2}\right]\left[\mathrm{H}^{+}\right]}{\left[\mathrm{HCO}_{3}{ }^{-}\right]}=4.69 \times 10^{-11}
\end{aligned}
$$

$\log K_{3}=-10.3$

From Eqs. (1) to (3), total $K_{1}, K_{2}$ and $K_{3}$ is

$$
\begin{aligned}
& \mathrm{CO}_{2}(\mathrm{~g})+\mathrm{H}_{2} \mathrm{O}(\mathrm{l}) \rightleftharpoons \mathrm{CO}_{3}{ }^{2-}+2 \mathrm{H}^{+} \\
& K=\frac{\left[\mathrm{CO}_{3}{ }^{2-}\right]\left[\mathrm{H}^{+}\right]^{2}}{P_{\mathrm{co}_{2}}} \\
& \log K=\log K_{1}+\log K_{2}+\log K_{3}=-18.2
\end{aligned}
$$

$\left[\mathrm{CO}_{3}{ }^{2-}\right]$ is

$$
\log \left[\mathrm{CO}_{3}{ }^{2-}\right]=\log K+\log P_{\mathrm{CO}_{2}}-2 \log \left[\mathrm{H}^{+}\right]
$$

Using $P_{\mathrm{CO}_{2}}=10^{-3.5}{ }^{25)}$ and from (4)

$$
\begin{aligned}
\log \left[\mathrm{CO}_{3}^{2-}\right] & =-18.2-3.5+2 \mathrm{pH} \\
& =-21.7+2 \mathrm{pH}
\end{aligned}
$$


From the ionic product of water

$$
\begin{aligned}
\mathrm{H}_{2} \mathrm{O} & =\mathrm{H}^{+}+\mathrm{OH}^{-} \\
\log K_{\mathrm{w}} & =\log \left[\mathrm{H}^{+}\right]\left[\mathrm{OH}^{-}\right]=-14.0 \\
\log \left[\mathrm{OH}^{-}\right] & =p H-14.0
\end{aligned}
$$

Hydrozincite is represented as $\mathrm{Zn}(\mathrm{OH})_{1.2}\left(\mathrm{CO}_{3}\right)_{0.4}$. Hydrozincite precipitation is ${ }^{26,27)}$

$$
\begin{aligned}
\mathrm{Zn}(\mathrm{OH})_{1.2}\left(\mathrm{CO}_{3}\right)_{0.4}(\mathrm{~s}) & \rightleftharpoons \mathrm{Zn}^{2+}+1.2 \mathrm{OH}^{-}+0.4 \mathrm{CO}_{3}^{2-} \\
K_{\mathrm{s}, \mathrm{Zn}(\mathrm{OH})_{1.2}\left(\mathrm{CO}_{3}\right)_{0.4}} & =\left[\mathrm{Zn}^{2+}\right]\left[\mathrm{OH}^{-}\right]^{1.2}\left[\mathrm{CO}_{3}^{2-}\right]^{0.4} \\
& =6.31 \times 10^{-15} \\
\log K_{\mathrm{s}, \mathrm{Zn}(\mathrm{OH})_{1.2}\left(\mathrm{CO}_{3}\right)_{0.4}} & =-14.2
\end{aligned}
$$

From (5), (6) and (7), $\left[\mathrm{Zn}^{2+}\right]$ is

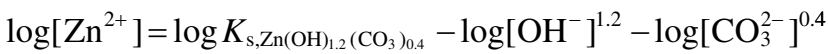

$$
\begin{aligned}
& =-14.2-1.2(\mathrm{pH}-14)-0.4(-21.7+2 \mathrm{pH}) \\
& =-2 \mathrm{pH}+11.3
\end{aligned}
$$

Consider simonkolleite: At $25^{\circ} \mathrm{C}$ in air and $90 \%$ relative humidity, water vapor equilibrates with water containing $\left[\mathrm{Cl}^{-}\right]=3.5(\mathrm{~mol} / \mathrm{g}){ }^{28)}$ Assume that the density $\rho=1.16$ $\left(\mathrm{g} / \mathrm{cm}^{3}\right)$ of the aqueous $\mathrm{NaCl}$ solution is ${ }^{29)}$

$$
\begin{aligned}
{\left[\mathrm{Cl}^{-}\right] } & =3.5(\mathrm{~mol} / \mathrm{g}) \\
& =\frac{3.5}{(1000+3.5 \times 58.5) \div 1.16}\left(\mathrm{~mol} / \mathrm{cm}^{3}\right) \\
& =10^{0.528}\left(\mathrm{~mol} / \mathrm{dm}^{3}\right)
\end{aligned}
$$

The solubility product of simonkolleite is ${ }^{24,30)}$

$$
\begin{aligned}
\mathrm{Zn}(\mathrm{OH})_{1.6} \mathrm{Cl}_{0.4}(\mathrm{~s}) & \rightleftharpoons \mathrm{Zn}^{2+}+0.4 \mathrm{Cl}^{-}+1.6 \mathrm{OH}^{-} \\
K_{\mathrm{s}, \mathrm{Zn}(\mathrm{OH}) .6 \mathrm{Cl}_{0.4}} & =\left[\mathrm{Zn}^{2+}\right]\left[\mathrm{OH}^{-}\right]^{1.6}\left[\mathrm{Cl}^{-}\right]^{0.4} \\
\log K_{\mathrm{s}, \mathrm{Zn}(\mathrm{OH})_{1.6} \mathrm{Cl}_{0.4}} & =-14.95
\end{aligned}
$$

From (9) and (10), $\left[\mathrm{Zn}^{2+}\right]$ is:

$$
\begin{aligned}
\log \left[\mathrm{Zn}^{2+}\right] & =\log K_{\mathrm{s}, \mathrm{Zn}(\mathrm{OH})_{.6} \mathrm{Cl} \operatorname{lo} .4}-\log \left[\mathrm{Cl}^{-}\right]^{0.4}-\log \left[\mathrm{OH}^{-}\right]^{1.6} \\
& =-14.95-0.4 \times 0.528-1.6(\mathrm{pH}-14) \\
& =-1.6 \mathrm{pH}+7.24
\end{aligned}
$$

From Eqs. (8) and (11), pH dependence of simonkolleite and hydrozincite is different. Figure 12 shows $\mathrm{pH}$ dependence of $\mathrm{Zn}^{2+}$ concentration with simonkolleite and hydrozincite. The $\mathrm{pH}$ at the intersection of simonkolleite and hydrozincite is $\mathrm{pH}=10.15$. Hydrozincite precipitates preferentially when $\mathrm{pH}>10.15$, and simonkolleite precipitates preferentially when $\mathrm{pH}<10.15$. Ogle et al. suggest that the $\mathrm{pH}$ going from steel to $\mathrm{Zn}$ falls from 11.5 to nearly 8.0 in simulated cut edge corrosion tests. ${ }^{31)}$ The calculation results shown in Fig. 12 and the results of this experiment agree with the results of Ogle et al.

According to the calculations, the deposition mechanism of $\mathrm{Zn}$ corrosion products changed with distance from formed scratch is shown in Fig. 13. An anodic reaction (dissolution of $\mathrm{Zn}$ ) occurs on $\mathrm{Zn}$ coating. At the substrate steel exposed

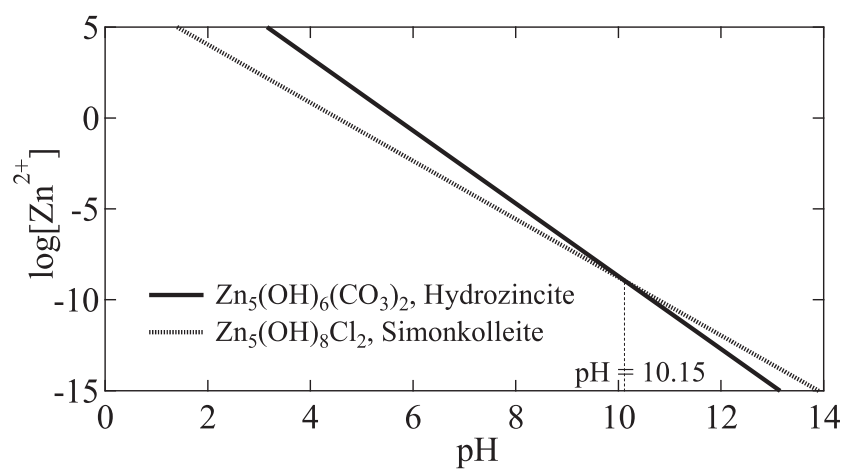

Fig. 12. $\mathrm{pH}$ dependence of $\mathrm{Zn}^{2+}$ concentration with simonkolleite and hydrozincite. The concentration of $\mathrm{NaCl}$ was assumed from the equilibrium with water vapor in $\mathrm{RH} 90 \%$.
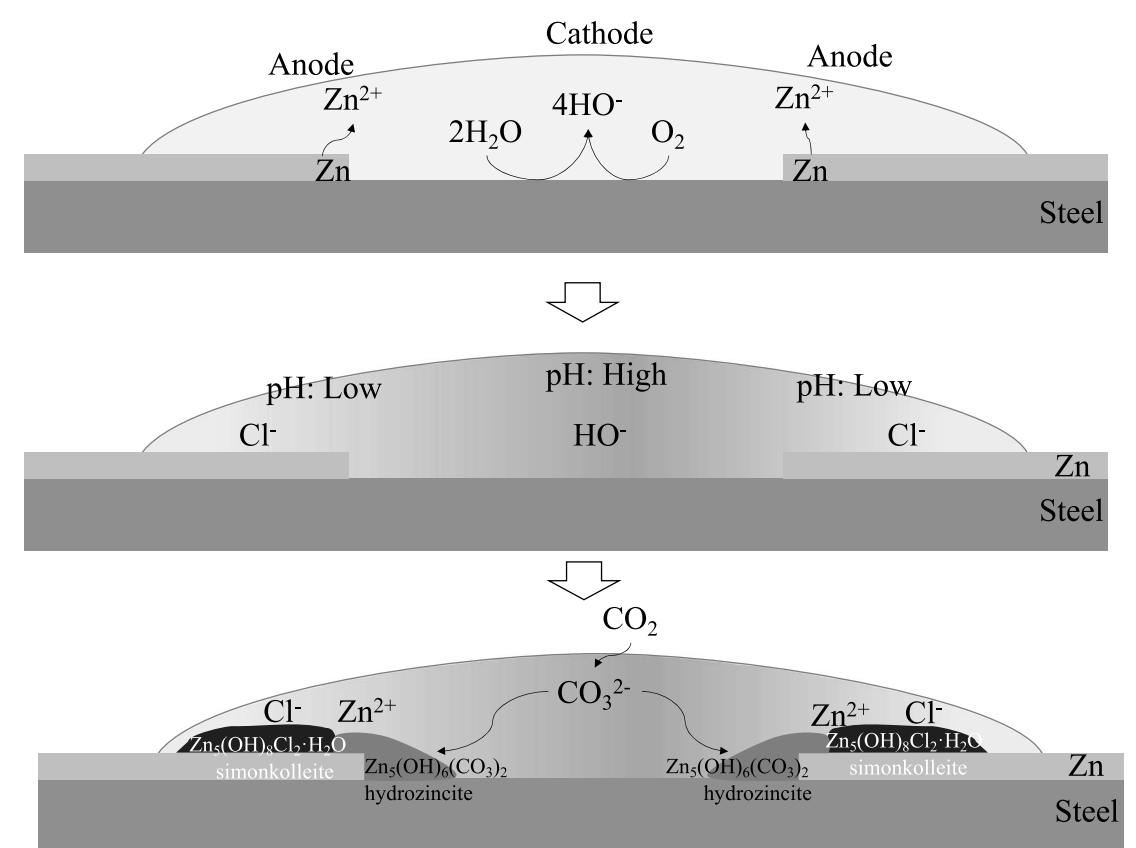

Fig. 13. Schematic drawing of precipitation of simonkolleite and hydrozincite around the scratch on $\mathrm{Zn}$ coated steel. 
to the solution, a cathode reaction (oxygen reduction reaction) occurs. The region have a high $\mathrm{pH}$ due to the oxygen reduction reaction. In the high $\mathrm{pH}$ region, $\mathrm{CO}_{3}{ }^{2-}$ is absorbed into the droplet and carbonate ions diffuse from the center of the scratch. As a result, hydrozincite deposits around the scratch, and simonkolleite deposits on the $\mathrm{Zn}$ coated region.

In this study, hydrozincite was observed on the surface of the specimen after the test (Fig. 7). This means that there were $\mathrm{pH}>10.15$ region in the solution layer. Since the amount of hydrogen generation decreases at high $\mathrm{pH}$, the amount of hydrogen permeation could be also decreased. It is also considered that the corrosion product covering the substrate steel reduced the hydrogen generation reaction (cathode reaction) region and also reduced the amount of hydrogen permeation.

\section{Conclusions}

A hydrogen permeation behavior of scratch on $\mathrm{Zn}$ coated steel during $1000 \mathrm{~h}$ wet and dry cycle corrosion was clarified. After $400 \mathrm{~h}$, hydrogen permeation peaks became several $\mathrm{nA}$. Protective layer of $\mathrm{Zn}$ corrosion products prevent hydrogen permeation. There are $\mathrm{Zn}$ oxide $(\mathrm{ZnO})$ on the substrate steel (at the formed scratch), hydrozincite $\left(\mathrm{Zn}_{5}(\mathrm{OH})_{6}\left(\mathrm{CO}_{3}\right)_{2}\right)$ around the scratch boundary and simonkolleite $\left(\mathrm{Zn}_{5}(\mathrm{OH})_{8} \mathrm{Cl}_{2}\right)$ on $\mathrm{Zn}$ coated region. The $\mathrm{pH}$ dependence of $\mathrm{Zn}^{2+}$ concentration with hydrozincite and simonkolleite was calculated. The calculated reslts suggested that hydrozincite deposit at high $\mathrm{pH}$ region (Steel/ $\mathrm{Zn}$ interface) and simonkolleite deposit at low $\mathrm{pH}$ region ( $\mathrm{Zn}$ coating). The presence of hydrozincite means that some parts of solution layer formed during each cycle was $\mathrm{pH}>$ 10.15. This high $\mathrm{pH}$ in the solution layer may reduce both the amount of hydrogen generation and permeation.

\section{Acknowledgements}

SEM observation of this work was conducted at the Laboratory of XPS analysis, Joint-use facilities, Hokkaido University, supported by "Material Analysis and Structure Analysis Open Unit (MASAOU). XPS analysis was conducted at the Laboratory of XPS analysis, Hokkaido University, supported by 'Nanotechnology Platform' Program of the Ministry of Education, Culture, Sports, Science and Technology (MEXT), Japan.

\section{REFERENCES}

1) D. Hardie, E. A. Charles and A. H. Lopez: Corros. Sci., 48 (2006), 4378.

2) I. Moro, L. Briottet, P. Lemoine, E. Andrieu, C. Blanc and G. Odemer: Mater. Sci. Eng. A, 527 (2010), 7252.

3) T. Schaffner, A. Hartmaier, V. Kokotin and M. Pohl: J. Alloy. Compd., 746 (2018), 557.

4) K. Doi, E. Akiyama and M. Hayakawa: ECS Trans., 75 (2017), 33.

5) H. Hatano, M. Fujinami, K. Arai, H. Fujii and M. Nagumo: Acta Mater., 67 (2014), 342.

6) T. Shinohara: J. Surf. Finish. Soc. Jpn., 62 (2011), 25 (in Japanese).

7) M. C. Bernard, A. Hugot-Le Goff and N. Phillips: J. Electrochem. Soc., 142 (1995), 2162.

8) T. Ohtsuka and Y. Abe: Proc. 7th Int. Conf. on Zinc and Zinc Alloy Coated Steel Sheet (Galvatech '07), ISIJ, Tokyo, (2007), 648.

9) T. Ohtsuka and M. Matsuda: Corrosion, 59 (2003), 407.

10) I. Odnevall and C. Leygraf: Corros. Sci., 36 (1994), 1551

11) E. Tada and Y. Miura: ISIJ Int., 56 (2016), 444.

12) K. Igarashi and M. Sakairi: ISIJ Int., 56 (2016), 465.

13) J. Kasperek and M. Lenglet: Rev. Metall. Paris, 94 (1997), 713.

14) N. Ikeo, Y. Iijima, N. Niimura, M. Sigematsu, T. Tazawa, S. Matsumoto, K. Kojima and Y. Nagasawa: Handbook of X-ray Photoelectron Spectroscopy, JEOL Ltd., Tokyo, (1991), 180.

15) J. Winiarski, W. Tylus, K. Winiarska, I. Szczygieł and B. Szczygieł: J. Spectrosc., 2018 (2018), 2079278.

16) M. S. Islam, K. Otani and M. Sakairi: ISIJ Int., 58 (2018), 1616.

17) M. S. Islam, K. Otani and M. Sakairi: Corros. Sci., 131 (2018), 17.

18) T. Sekine, Y. Nagasawa, M. Kudoh, Y. Sakai, A. S. Parkes, J. D. Geller, A. Mogami and K. Hirata: Handbook of Auger Electron Spectroscopy, JEOL Ltd., Tokyo, (1982), 28.

19) K. Tsutsumi, A. Tanaka, M. Shima and T. Tazawa: J. Surf. Sci. Soc. Jpn., 33 (2012), 431 (in Japanese).

20) K. Tsutsumi: J. Surf. Finish. Soc. Jpn., 66 (2015), 621 (in Japanese).

21) K. Tsutsumi, Y. Nagasawa, H. Watanabe and S. Endo: Proc. 26th Annual Meeting of the Surface Science Society of Japan, The Surface Science Society of Japan, Tokyo, (2006), 4D23 (in Japanese). https:// doi.org/10.14886/sssj.26.0.290.0

22) K. Tsutsumi, A. Tanaka and M. Shima: Proc. Japan Society of Vacuum and Surface Science Conf., JVSS, Tokyo, (2018), 3Bp11 (in Japanese). https://doi.org/10.14886/sssj2008.2018.0 336

23) S. M. Manhabosco, T. M. Manhabosco, N. Geoffroy, $\bar{V}$. Vignal and L. F. P. Dick: Corros. Sci., 140 (2018), 379.

24) N. Okada, M. Matsumoto, K. Nishihara, M. Kimoto, T. Kudo and S. Fujimoto: Tetsu-to-Hagané, 97 (2011), 108 (in Japanese).

25) W. Stumm and J. J. Morgan: Aquatic Chemistry, 3rd ed., John Wiley and Sons, Hoboken, NJ, (1996), 192.

26) W. Stumm and J. J. Morgan: Aquatic Chemistry, 2nd ed., John Wiley and Sons, Hoboken, NJ, (1981), 204.

27) H. Tamura: Tetsu-to-Hagané, 89 (2003), 1165 (in Japanese).

28) T. Shinohara: Zairyo-to-Kankyo, 51 (2002), 126 (in Japanese).

29) National Astronomical Observatory of Japan, ed.: Rika Nenpyo (Chronological Scientific Tables), Maruzen Co., Ltd., Tokyo, (2008), 375 (in Japanese).

30) N. Okada, K. Nishihara and M. Matsumoto: Shinnittetsu Sumikin Giho, 410 (2018), 64 (in Japanese).

31) K. Ogle, V. Baudu, L. Garrigues and X. Philippe: J. Electrochem. Soc., 147 (2000), 3654. 